\title{
Health Education for Peon to Improve Infection Prevention Practices in Government Health Facilities of Morang
}

\author{
Gurung G. ${ }^{1}$ Dahal S² \\ ${ }^{1}$ Save the Children US. Nepal Familv Health Program. Kathmandu. ${ }^{2}$ Evidemiologv and Disease Control Division. Kathmandu. \\ Nepal
}

\section{ABSTRACT}

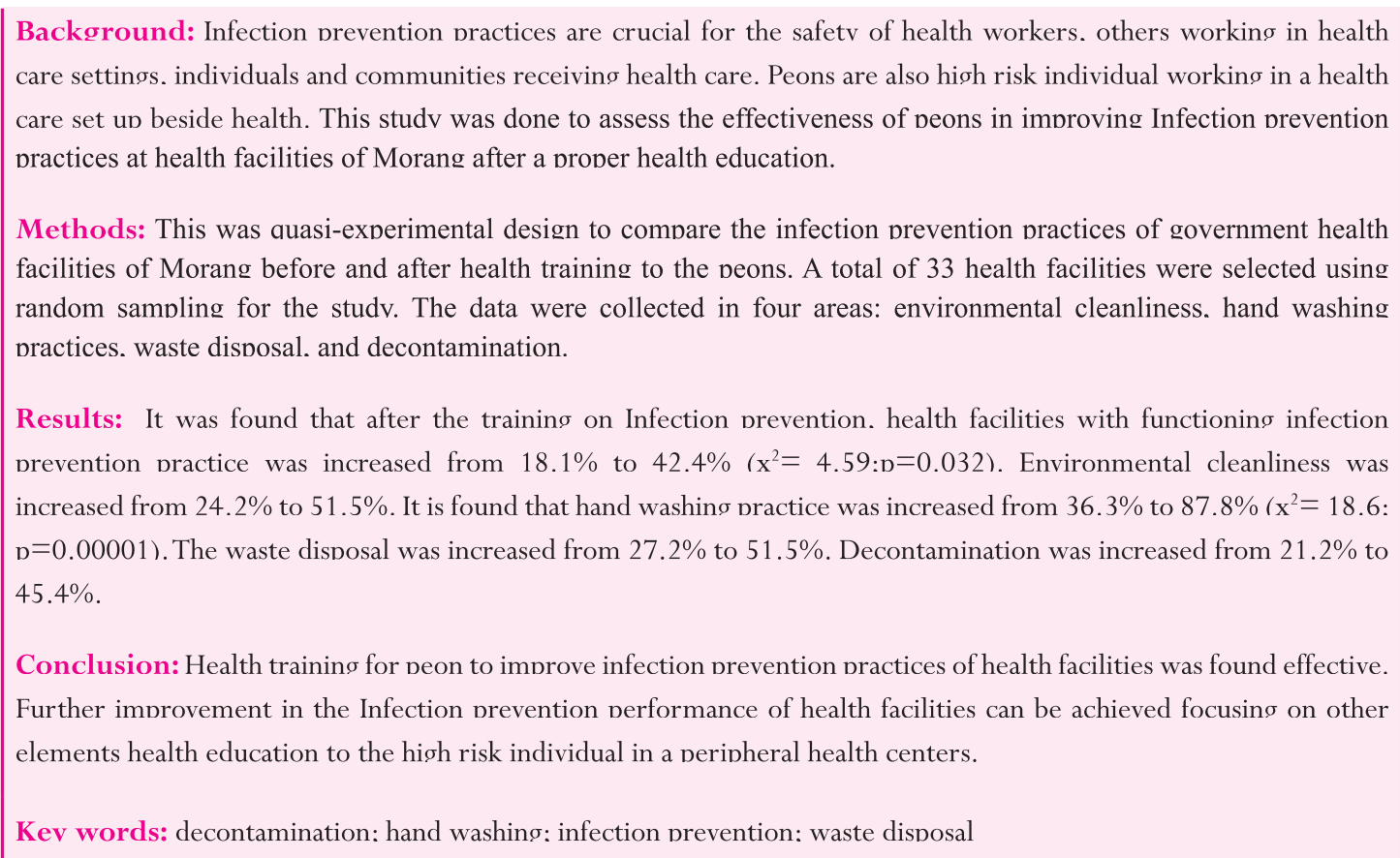

\section{INTRODUCTION}

Maioritv of morbiditv and mortalitv is related to infectious diseases especiallv in the develobing countrv. Over the Dast decades. the world has seen increased outbreaks of the disease that were once under controlled. Health care personnel and others working in the health care settings are on the front line of protecting themselves and their clients from infectious diseases. ${ }^{1}$ Thev
Derform clinical procedures or other activities that can expose themselves and clients to potentiallv infectious microorganisms. Health care-associated infections lead to death. disabilitv and excess medical costs. ${ }^{2}$ Hospital/ health facilities (HFs) acauired infection is called nosocomial infection. ${ }^{3}$ One estimation shows that about three million health workers worldwide are exposed to 
Dathogens such as hepatitis $B$ virus (HBV). hepatitis $C$ virus (HCV) and HIV each vear through percutaneous iniuries. And more than $90 \%$ of these infections occur in developing countries. where health workers often lack the knowledge. skills and resources necessarv to protect themselves and their clients from becoming infected. ${ }^{4}$ Infection Prevention (IP) practices are crucial for the safetv of health workers. others working in health care settings. individuals obtaining health care. and the communities in which thev live. Even with limited staff. equipment. and funds. health care facilities in the developing world can fight deadlv diseases bv following some simble. cost-effective procedures. ${ }^{5}$ Infection prevention and control maximize patient satisfaction and also reduces the cost of health services. ${ }^{6}$

Peons. are non-health professional individual who are a part of a health care svstem vet thev have rarelv been included in anv health education concerning the maintenance of a healthv environment and in the prevention of cross infection. Joint monitoring of the HFs bv District Public Health Office (DPHO) and Save the Children. showed the need to train peons on IP. An assessment of IP practices of $33 \mathrm{HFs}$ was done. Save the Children US, in collaboration with DPHO Morang. organized five davs training. for all the Deons in the district. to improve and svstematize the existing infection prevention practices of their dailv work. The training used internationallv accepted but low-tech approaches that are practical. simple and inexpensive. The main contents of the training were disease transmission. hand washing. gloving. and waste disposal including others. The methods used in this training included three davs micro-teaching followed bv two davs field practices. After the training. follow up was done focusing on onsite coaching in that HFs. This studv was therefore designed to know the exact situation of IP practices in government HFs and to combare IP practices before and after health education to the peons.

\section{METHODS}

A auasi-experimental studv design to assess the effectiveness of the capacitv building measure to peons on IP practices in Primarv Health Care Centers (PHCCs). Morang. A survev to assess the IP practices of the sample HFs was done from March10. 2005 to March 20. 2005. Then IP training was conducted from March 30 to April 8. 2005 at the sample HFs. A standard training manual develoned bv Save the Children US was used. The training was comblemented bv intensive follow-up for six to eight months which was focused on on-site coaching. The IP training and the coaching during follow-ud was taken as the capacitv building intervention to peons. Then another assessment at the same samble HFs was done on Februarv 2006. Standard infection prevention observation checklist/quideline was used to collect data from HFs. Out of $66 \mathrm{HFs}$. 33HFs comprising three PHCCs. seven Health Posts (HPs). and 23 Sub- Health Posts (SHPs) were randomlv selected using simble random sampling technique. Detailed list of Health facilities were prepared and desired samble size was chosen using lotterv method. The operational definition for the functioning of IP practices of HFs in this studv was HF which have fulfilled all four criterias: environmental cleanliness, hand washing practices.waste disposal and decontamination/high level disinfection (HLD). Before collecting data. Dermission was taken from DPHO. Morang and verbal consent was taken from respondents. TFour areas were chosen to see the situation of IP practices in HFs which was used and accepted internationallv. These areas were environmental cleanliness. hand washing practices. west disposal. and decontamination. ${ }^{6.7}$ Data were entered and analvzed using Evi info 3.2.2.

\section{RESULTS}

\section{Environmental cleanliness}

Under this heading there were four indicators. There was increase in proportion of clean health facilities from $24.2 \%$ before training to $51.5 \%$ dafter training follow uD.

\section{Hand washine practices}

Hfs with both facilities for hand washing and practice of hand washing bv Deons is found increased from $36.3 \%$ to $87.8 \%$.

\section{Table 1. Environmental cleanliness $(\mathrm{N}=33)$}

\begin{tabular}{|lllll|}
\hline SN & Indicators & before & After & Difference (\%) \\
\hline 1 & Clean floors of HF & $11(33.3 \%)$ & $25(75.7 \%)$ & 42.4 \\
2 & Clean combound of HF & $9(27.2 \%)$ & $27(81.8 \%)$ & 54.6 \\
3 & Clean dressing tables & $10(30.3 \%)$ & $22(66.6 \%)$ & 36.3 \\
4 & Clean toilets & $8(24.2 \%)$ & $21(63.6 \%)$ & 39.4 \\
5 & HF with clean environment (with above 1. 2. 3.4) & $8(24.2 \%)$ & $17(51.5 \%)$ & 27.3 \\
\hline \hline
\end{tabular}




\section{Waste disposal}

The waste disposal practice was found increased from $27.2 \%$ to $51.5 \%$. However. practices of burning svringes and needles were not quite satisfactorv with onlv $6 \%$ increase before and after capacitv building measures but practices of waste disposal on puncture proofed medical waste container improved quite significantlv with $57.6 \%$ increase before and after training.

\section{Decontamination/High Level Disinfection (HLD)}

Practice of Decontamination/HLD before the capacitv building measures was found verv low (21.2\%) which was increased to $45.4 \%$. The reason for low level of decontamination/HLD was due to Door subplv of material (Chlorine. gloves and kerosene oil). In $10 \mathrm{HFs}$ ( 3 PHCs and $7 \mathrm{HDs}$ ). practice of sterilization is also assessed which was slightlv increased from $40 \%$ to $60 \%$ after the capacitv building measure.

\section{Health Facilities with functioning IP practices}

HF with functioning IP practices were increased from $18.1 \%$ to $42.4 \%$. Before the capacitv building intervention. all area of infection prevention were found verv poor. But after training and follow uD. IP practices were improved considerablv.

\begin{tabular}{|l} 
Table 2 . Hand washing Dractices $(\mathrm{N}=33)$ \\
\begin{tabular}{|llccc|}
\hline SN & Indicators & Before & After & Difference $(\%)$ \\
\hline 1 & Facilities for hand washing & $14(42.4 \%)$ & $29(87.8 \%)$ & 45.4 \\
2 & Trained peon washed their hand with soap & $15(45.4 \%)$ & $31(93.9 \%)$ & 48.5 \\
3 & HF with hand washing practices (above 1 and 2) & $12(36.3 \%)$ & $29(87.8 \%)$ & 51.5 \\
\hline
\end{tabular}
\end{tabular}

\begin{tabular}{|c|c|c|c|c|}
\hline SN & Indicators & Before & After & Difference $(\%)$ \\
\hline 1 & Waste disposed on puncture proofed and medical waste container & $12(36.3 \%)$ & $31(93.9 \%)$ & 57.6 \\
\hline 2 & Pit or incinerator available & $12(36.3 \%)$ & $24(72.7 \%)$ & 36.4 \\
\hline 3 & Burning svringe and needles regularlv & $18(54.5 \%)$ & $20(60.6 \%)$ & 6.1 \\
\hline 4 & Burning combustible items regularlv & $19(57.5 \%)$ & $27(81.8 \%)$ & 24.3 \\
\hline 5 & HF with waste disposal practice (having all 1-4) & $9(27.2 \%)$ & $17(51.5 \%)$ & 24.3 \\
\hline
\end{tabular}

\section{Table 4. Decontamination/ HLD (N=33)}

\begin{tabular}{|lllll|}
\hline SN & Indicators & Before & After & Difference (\%) \\
\hline 1 & Peon has put the instruments in chlorine solution & $8(24.2 \%)$ & $16(48.4 \%)$ & 24.2 \\
2 & Peon used utilitv gloves while cleaning instrument & $7(21.2 \%)$ & $18(54.5 \%)$ & 33.3 \\
3 & Peon has dipped maintained correct timing for boiling instrument & $7(21.2 \%)$ & $2369.69 \%)$ & 48.49 \\
4 & HF with Decontamination/HLD practice (1. 2. 3) & $721.2 \%)$ & $15(45.4 \%)$ & 24.2 \\
\hline
\end{tabular}

\section{Table 5. Health Facilities with functioning IP practices $(\mathbf{N}=33)$}

\begin{tabular}{|llcccl|}
\hline SN & Indicators & Before & After & Difference $(\%) \times 2$ \\
\hline 1 & HF with environment cleanliness & $8(24.2 \%)$ & $17(51.5 \%)$ & 27.3 & $5.22(\mathrm{df}=1 . \mathrm{D}=0.022)$ \\
2 & HF with hand washing practices & $12(36.3 \%)$ & $29(87.8 \%)$ & 51.5 & $18.6(\mathrm{df}=1 . \mathrm{D}=0.00001)$ \\
3 & HF with waste disposal Dractice & $9(27.2 \%)$ & $17(51.5 \%)$ & 24.3 & $4.1(\mathrm{df}=1 . \mathrm{D}=0.043)$ \\
4 & HF with decontamination/HLD practice & $7(21.2 \%)$ & $15(45.4 \%)$ & 24.2 & $4.36(\mathrm{df}=1 . \mathrm{D}=0.036)$ \\
5 & HF with functioning IP practice (1. 2. 3. 4) & $6(18.1 \%)$ & $14(42.4 \%)$ & 24.3 & $4.59(\mathrm{df}=1 . \mathrm{D}=0.032)$ \\
\hline \hline
\end{tabular}




\section{DISCUSSION}

The term capacitv building is intangible and vaque. What constitute capacitv building in practice can varv enormouslv. and the concedt continues to develon as field experience grows. In earlv davs manv equated capacitv building with training. Todav it is accepted that individual skills are onlv part of the complex mixture of elements that constitute capacitv to perform a certain function effectivelv. ${ }^{8}$ Capacitv building in this studv was defined in terms of training and continuous support/ on-site coaching to peon in reference to IP. This studv was focused at the measuring effect of increased IP knowledge and skills of peons in IP practices of HFs. Four maior areas: environment cleanliness. hand washing. waste disposal and decontamination/HLD were focused during training and follow-up. All together 13 indicators were developed in these 4 areas to measure the performance improvement of IP practices in HFs. An index indicator (HFs with functioning IP practice) was used combining four maior indicators (HFs with clean environment. hand washing practices. waste disposal practice and decontamination/HLD) to define whether a HF has functioning IP practice or not. It was found that after training and on-site coaching during follow uD. HF with functioning IP practice got increased from $18.1 \%$ to $42.4 \%\left(x^{2}=4.59 . d f=1 . P=0.032\right)$. It was found that hand washing practices is found quite satisfactorv $(87.8 \%)$ whereas practice of decontamination/HDL is not increased significantlv. A studv conducted in Morang found that hand washing practices was found auite high $(94.1 \%) .{ }^{9}$ Table 4 shows that the practice of decontamination/HDL was increased from $21.2 \%$ before training to $45.4 \%$ after the training/follow-uD. The use of gloves $(54.5 \%)$ and chlorine solution $(48.4 \%)$ is still auite low even after capacitv building intervention. It might be due to the lack of gloves and chlorine solution available in Hfs. Literature on effectiveness of IP training to supporting staff/peon is scarce. Available literatures showed that there was no such studv conducted before in Nebal. A waste disposal and safetv measure training to Deons conducted bv Care Nepal showed Dositive outcome with increased waste disposal and safetv measure in peripheral health facilities of 7 districts of Nepal. ${ }^{10}$ Capacitv building is multi-dimensional issues and intervention on onlv one area of health svstem cannot improve the overall performance. ${ }^{8}$ This studv indicates that over all improvement in the IP practices of HFs need regular supdlv/availabilitv of materials like kerosene. chlorine solution. maintenance of sterilizer. boiler. soap. hand towel. bucket. water etc. The capacitv building measures to peons/health worker is onlv one aspect to improve the IP performance of health facilities. It is also observed that training to health workers on IP is equallv important to improve the IP Derformance of HFs. It is therefore concedt of wholesite training is verv necessarv in which peon. HF staff. Health Facilitv Operation and Management Committee (HFOMC) need to be trained. HFOMC who is supposed to manage local HF would help to solve issues of supplv with local resources. ${ }^{11}$
Even though a cost effective studv design. auasiexperimental design has no comparison groups. therefore difficulties in establishment of cause and effect relationship and it does not take in to account temporal change. ${ }^{12}$ One can argue that temporal changes and others factors would also affect in the change in IP practices.

In Nedal. the peon. the lowest ranking worker in the health services. Derforms manv basic and crucial functions. Their contribution is remains invisible. ${ }^{13}$ This tvpe of the training would reallv increase their motivation and thev can be protected from unwanted health hazards.

\section{CONCLUSIONS}

It can be concluded that capacitv building of peon to improve IP practice in government HFs of Morang was verv effective. Therefore it is recommended to train the peons on IP using low-tech approaches that are practical and simble to improve IP practices of peribheral governmental HFs.

\section{REFERENCES}

1. Enoender Health. Infection prevention. A reference Booklet for Health Care Providers. 2001.

2. World Health Oroanization. Infection control. AIDE-MEMOIRE for Infection Prevention and Control in Health Care Facilitv. 2004

3. Park K. Park's Textbook of Preventive and Social Medicine18th ed. Banarsidas Bhanot Publisher 2005 (Chapater 3):85-87.

4. IHPIEGO. Infection Prevention and Control-Available from website-www.ihnie $\sigma_{0}$.or $\sigma /$ centers/inc.html/ (accessed 2008).

5. End $\sigma$ enderHealth. Infection Prevention Online Course. IAccessed 2007l. Available from: URL:htto://www.enoenderhealth.or $\sigma /$ res/onc/about/about-ip.html

6. Shrestha D. Helpin $\sigma$ Books for Infection Prevention. 2nd ed. Engender Health. Nepal. 2002:1-18.

7. Disease Prevention and Control Debartment of Ethiopia. Infection prevention guidelines for health care facilities in Ethiopia 2004.

8. MEASURE Evaluation Proiect. A suide to monitoring and evaluation of capacitv-Building Intervention in the Health Sector in Develoning Countries. MEASURE Evaluation Manual Series 7:2003.

9. Subba N. Gurung G. A studv of public health indicators of Morang Nepal bv lot aualitv assurance sampling method. Nepal Med Coll I. 2007 Iune: 9:117-19.

10. Care Nebal. Proiect completion report. 2007

11. National Health Training Center. Teku. Directives for local health facilitv hand over and operation 2003.

12. Thomas S. Before and After Studv Desions in Iniurv Research 2005. IAccessed 20081 Available from: URL:httb://www.pitt. edu/ $\sim_{\text {tis } / \text { httb: / / www. pitt.edu/ } \sim \text { epi2670/beforeafter/ }}$

13. Iustice I. The invisible worker: the role of the peon in Nepal's health service Social Science and Medicine. 1983:17:967-70. 